\title{
Pycnophyes dolichurus sp. nov. and $P$. aulacodes sp. nov. (Kinorhyncha, Homalorhagida, Pycnophyidae), two new kinorhynchs from Spain with a reevaluation of homalorhagid taxonomic characters
}

\author{
Nuria Sánchez • Fernando Pardos • María Herranz • \\ Jesús Benito
}

Received: 11 February 2010/Revised: 1 September 2010/Accepted: 5 September 2010/Published online: 10 November 2010 (C) Springer-Verlag and AWI 2010

\begin{abstract}
Two new species of the kinorhynch genus Pycnophyes are described from the Atlantic Ocean, Northwest Spain, and the Mediterranean Sea, East of Spain, using differential interference contrast microscopy and scanning electron microscopy (SEM): Pycnophyes dolichurus sp. nov. and $P$. aulacodes sp. nov. Taxonomic characters from cuticular structures in homalorhagids are discussed and reevaluated. The longitudinal positions of cuticular structures along the trunk are furthermore defined, and the positional terminology is standardized. The distribution of the genus Pycnophyes in European waters is revised, revealing a poor knowledge of kinorhynch biogeography, probably due to incomplete sampling.
\end{abstract}

Keywords Pycnophyes - Kinorhyncha - Meiofauna . Geographic distribution - Cuticular characters · Taxonomy

\section{Introduction}

Kinorhyncha is a phylum of meiobenthic animals. Their total lengths never exceed more than $1 \mathrm{~mm}$, and they are found in marine or estuarine sediments exclusively, from coarse sand or shell gravel to very fine mud (Higgins 1964a, 1983, 1988). Their body is covered by cuticle and divided into an anterior, eversible introvert with scalids, a neck and a trunk with 11 segments. For a description of the

Communicated by Peter Funch.

N. Sánchez · F. Pardos $(\bowtie) \cdot M$. Herranz · J. Benito Dpto. Zoología y Antropología Física, Facultad de Biología, Universidad Complutense de Madrid, C/ José Antonio Novais 2, 28040 Madrid, Spain

e-mail: fpardos@bio.ucm.es general anatomy and taxonomic characters of kinorhynchs, see Higgins (1983), Kristensen and Higgins (1991), and Sørensen and Pardos (2008).

The order Homalorhagida Zelinka, 1896 comprises two families: Neocentrophyidae Higgins, 1969 and Pycnophyidae Zelinka, 1896, of which the latter is characterized by having the first trunk segment consisting of one tergal and one sternal plate. The sternal plate may be either partially or completely divided into three additional subunits: two episternal plates and one midsternal. Segments 2-11 are composed of one tergal and two sternal plates. Unlike many other species of kinorhynchs, members of the family Pycnophyidae have no middorsal spines on the trunk segments; however, many species present keel-like middorsal, posteriorly directed processes. Furthermore, cuticular setae may be present in various positions (Higgins 1983, 1988). The family Pycnophyidae comprises two genera: Pycnophyes and Kinorhynchus, which can be discriminated by the absence of lateral terminal spines in the latter, whereas species of Pycnophyes show lateral terminal spines on segment 11 in both sexes. Males of Pycnophyes can be distinguished from females by the presence of ventrolateral tubules on segment 2 and penile spines on the terminal trunk segment (Zelinka 1928).

Currently, the genus Pycnophyes includes 43 species. Eleven species have been recorded from European waters: 7 in the Atlantic (Table 1) and 8 in the Mediterranean (Table 2), with 4 species being present in both waters. Furthermore, species of other homalorhagid genera have been found in European waters: Kinorhynchus and Paracentrophyes have been reported from the Atlantic and Mediterranean (see references in Higgins and Adrianov 1991; Adrianov and Malakhov 1999; Sørensen and Pardos 2008; Sørensen et al. 2010). Pycnophyes quadridentatus Zelinka, 1928 and P. flagellatus Zelinka, 1928 were 
Table 1 Atlantic European species of Pycnophyes

\begin{tabular}{lll}
\hline Species & Locality & Reference \\
\hline Pycnophyes zelinkaei Southern, 1914 & Ireland, Clew Bay & Southern (1914) \\
& UK, Fladden & McIntyre (1962) \\
P. calmani (Southern, 1914) & Ireland, Clew Bay & Southern (1914) \\
& UK, St. Andrews Bay & Zelinka (1928) \\
& Ireland, Irish coast & Zelinka (1928) \\
& Denmark, Gilleleje Flak (Øresund) & Lang (1936) \\
& Clay Deep, North Sea & Huys and Coomans (1989) \\
P. dentatus (Reinhard, 1881) & Ireland, Clew Bay & Southern (1914) \\
& Germany, Kiel Bay & Zelinka (1928) \\
& Netherlands, Scheveningen & Zaneveld (1938) \\
P. communis Zelinka, 1908 & UK, Isle of Man & Bruce et al. (1963) \\
& Germany, Helgoland, Sylt (North Sea) & Neuhaus (1993) \\
P. kielensis Zelinka, 1928 & Sweden, Gullmar Fjord & Nyholm (1947) \\
& Sweden, Gullmar Fjord & Nyholm (1947) \\
& Denmark, Gilleleje Flak (Øresund) & Lang (1936) \\
& Germany, Kiel Bay & Zelinka (1928) \\
& Denmark, Vedbæk (Øresund) & Lang (1936) \\
& Germany, Greifswalder Boden & Reimer (1963) \\
& Germany, Helgoland, Sylt (North Sea) & Neuhaus (1988) \\
& Germany, Kadetrinne & Reimer (1963) \\
\hline
\end{tabular}

Table 2 Mediterranean European species of Pycnophyes

\begin{tabular}{lll}
\hline Species & Locality & Reference \\
\hline Pycnophyes communis Zelinka, 1908 & Italy, Naples Gulf & Zelinka (1928) \\
& Italy, Trieste Gulf & Zelinka (1928) \\
P. robustus Zelinka, 1928 & Italy, Naples Gulf & Zelinka (1928) \\
& Italy, Trieste Gulf & Zelinka (1928) \\
P. carinatus Zelinka, 1928 & Italy, Naples Gulf & Zelinka (1928) \\
& Italy, Trieste Gulf & Zelinka (1928) \\
P. flaveolatus Zelinka, 1928 & Italy, Naples Gulf & Zelinka (1928) \\
& Italy, Trieste Gulf & Zelinka (1928) \\
P. rugosus Zelinka, 1928 & Italy, Naples Gulf & Zelinka (1928) \\
P. ponticus (Reinhard, 1881) & Ukrania, Odessa, Black Sea & Reinhard (1881) \\
& Italy, Naples Gulf & Zelinka (1928) \\
& Rumania, Black Sea & Bãcescu and Bãcescu (1956) \\
& Bulgaria, Black Sea & Marinov (1964) \\
& Russia, Black Sea & Sheremetevskij (1974) \\
P. dentatus (Reinhard, 1881) & Ukrania, Odessa, Black Sea & Reinhard (1881) \\
& Rumania, Black Sea & Bãcescu and Bãcescu (1956) \\
& Russia, Black Sea & Sheremetevskij (1974) \\
P. kielensis Zelinka, 1928 & Ukrania, Odessa, Black Sea & Reinhard (1881) \\
& Rumania, Black Sea & Bãcescu (1968) \\
& Russia, Black Sea & Sheremetevskij (1974) \\
\hline
\end{tabular}

Along the Spanish coasts, species of Pycnophyes have not previously been recorded, and studies on kinorhynchs in Spain have been limited to the cyclorhagid genus Echinoderes. E. canariensis Greeff, 1869 was described from the Canary Islands but was later considered as species 
inquirendum (Pardos et al. 1998). E. dujardinii was reported from the Baleares Islands (Pagenstecher 1875), and in 1998 two new species were described from the Cantabric Sea (NW Spain): E. hispanicus Pardos et al. (1998), and E. cantabricus Pardos et al. (1998), followed in 2008 by three additional new species: E. isabelae $\mathrm{G}^{\mathrm{a}}$ Ordóñez et al. (2008), E. parrai $\mathrm{G}^{\mathrm{a} O r d o ́ n ̃ e z ~ e t ~ a l . ~(2008), ~ a n d ~ E . ~ n e o s p i-~}$ nosus $\mathrm{G}^{\mathrm{a} O r d o ́ n ̃ e z ~ e t ~ a l . ~(2008) ~(s e e ~} \mathrm{G}^{\mathrm{a}}$ Ordóñez et al. 2008).

The aim of the present paper is to describe two new species of the genus Pycnophyes from the Spanish coastsone from the Atlantic coast and one from the Mediterranean. These species are the first pycnophyids reported for the Iberian Peninsula and the first new species of Pycnophyes from the Mediterranean Sea since the times of Zelinka's monography in 1928. Furthermore, the present paper offers a complete and up-to-date overview of the Pycnophyes species distribution in the European coasts.

\section{Materials and methods}

Specimens of Pycnophyes were collected at various localities in the Mediterranean and Atlantic coasts. Data on sampling localities, including position, type of the sediment, and depth are summarized in Table 3. Mediterranean sampling localities included Garrucha (Almería, SE Spain) and Denia (Alicante, E Spain), visited in 1997, and Blanes (Gerona, NE Spain) in 1999. Sampling along the Atlantic coasts included stations in the fjords Ría de Ferrol and Ría de Ares (La Coruña, NW Spain) in 2007 and in Ría de La Coruña and Ría de Ares (La Coruña, NW Spain) in 2008 (Fig. 1). All samples were subtidal, and although exact depths are not available for all sampling stations, the deepest locality was in the Ría de Ares, with $45.4 \mathrm{~m}$.

Sediment samples were taken using a Higgins Meiobenthic Dredge (Higgins 1964b, 1988) that collects the upper centimeters of sediment. The meiofauna was extracted from sediment samples using the bubble and blot method (Higgins 1964b, 1988; Sørensen and Pardos 2008). Samples were fixed with $7-10 \%$ formalin and dyed with Rose Bengal. Three hundred kinorhynch specimens were sorted under a dissecting microscope and mounted for LM either on regular slides or on Cobb-slides with either Hoyer's medium or Fluoromount- $\mathrm{G}^{\circledR}$, following standard procedures (Sørensen and Pardos 2008). The specimens were observed and photographed using an Olympus BX51
Table 3 Sampling localities for Pycnophyes dolichurus sp. nov. and $P$. aulacodes sp. nov., including number of specimens obtained $(n)$, geographic coordinates, type of sediment, depth, and type locality (*)

\begin{tabular}{|c|c|c|c|c|c|c|}
\hline Sample & n P. dolichurus & $n$ P. aulacodes & Locality & Coordinates & Sediment & Depth (m) \\
\hline 970324.1B & 0 & 1 & Garrucha & $\begin{array}{l}37^{\circ} 9^{\prime} 13.97^{\prime \prime} \mathrm{N} \\
1^{\circ} 47^{\prime} 57.12^{\prime \prime} \mathrm{W}\end{array}$ & Coarse sand & - \\
\hline 970325.3B & 0 & 1 & Garrucha & $\begin{array}{l}37^{\circ} 10^{\prime} 55.53^{\prime \prime} \mathrm{N} \\
1^{\circ} 49^{\prime} 30.3^{\prime \prime} \mathrm{W}\end{array}$ & Mud & - \\
\hline $970327.2 \mathrm{~B}$ & 0 & 6 & Denia & $\begin{array}{l}38^{\circ} 50^{\prime} 14^{\prime \prime} \mathrm{N} \\
0^{\circ} 9^{\prime} 25^{\prime \prime} \mathrm{E}\end{array}$ & Fine sand & - \\
\hline $990324.3 B$ & 0 & 1 & Blanes & $\begin{array}{l}41^{\circ} 38.596^{\prime} \mathrm{N} \\
02^{\circ} 46.255^{\prime} \mathrm{E}\end{array}$ & Midfine sand & - \\
\hline 070626.5 & 0 & 1 & Ría de Ferrol & $\begin{array}{l}43^{\circ} 28.178^{\prime} \mathrm{N} \\
008^{\circ} 14.716^{\prime} \mathrm{W}\end{array}$ & Mud & - \\
\hline $070627.1^{*}$ & 0 & 15 & Ría de Ares & $\begin{array}{l}43^{\circ} 25.064^{\prime} \mathrm{N} \\
008^{\circ} 16.558^{\prime} \mathrm{W}\end{array}$ & Mud & - \\
\hline $070627.3 *$ & 13 & 1 & Ría de Ares & $\begin{array}{l}43^{\circ} 24.844^{\prime} \mathrm{N} \\
008^{\circ} 17.832^{\prime} \mathrm{W}\end{array}$ & Coarse sand & - \\
\hline 070627.5 & 0 & 2 & $\begin{array}{l}\text { Ría de Ferrol } \\
\text { San Cristobo }\end{array}$ & $\begin{array}{l}43^{\circ} 27.887^{\prime} \mathrm{N} \\
008^{\circ} 18.118^{\prime} \mathrm{W}\end{array}$ & $\begin{array}{l}\text { Midfine sand } \\
\text { Muddy }\end{array}$ & - \\
\hline 080403.3 & 0 & 1 & Ría Coruña & $\begin{array}{l}43^{\circ} 22.208^{\prime} \mathrm{N} \\
008^{\circ} 21.177^{\prime} \mathrm{W}\end{array}$ & Midfine sand & 19 \\
\hline 080403.4 & 0 & 1 & Ría Coruña & $\begin{array}{l}43^{\circ} 22.718^{\prime} \mathrm{N} \\
008^{\circ} 21.858^{\prime} \mathrm{W}\end{array}$ & Fine sand & 27 \\
\hline 080403.6 & 0 & 1 & Ría Coruña & $\begin{array}{l}43^{\circ} 21.697^{\prime} \mathrm{N} \\
008^{\circ} 22.713^{\prime} \mathrm{W}\end{array}$ & $\begin{array}{l}\text { Midfine sand } \\
\text { Muddy }\end{array}$ & 19.1 \\
\hline 080404.3 & 21 & 1 & Ría de Ares & $\begin{array}{l}43^{\circ} 25.400^{\prime} \mathrm{N} \\
008^{\circ} 20.769^{\prime} \mathrm{W}\end{array}$ & Fine sand & 45.4 \\
\hline 080404.5 & 0 & 4 & Ría de Ares & $\begin{array}{l}43^{\circ} 23.232^{\prime} \mathrm{N} \\
008^{\circ} 15.391^{\prime} \mathrm{W}\end{array}$ & Fine sand & 13 \\
\hline
\end{tabular}




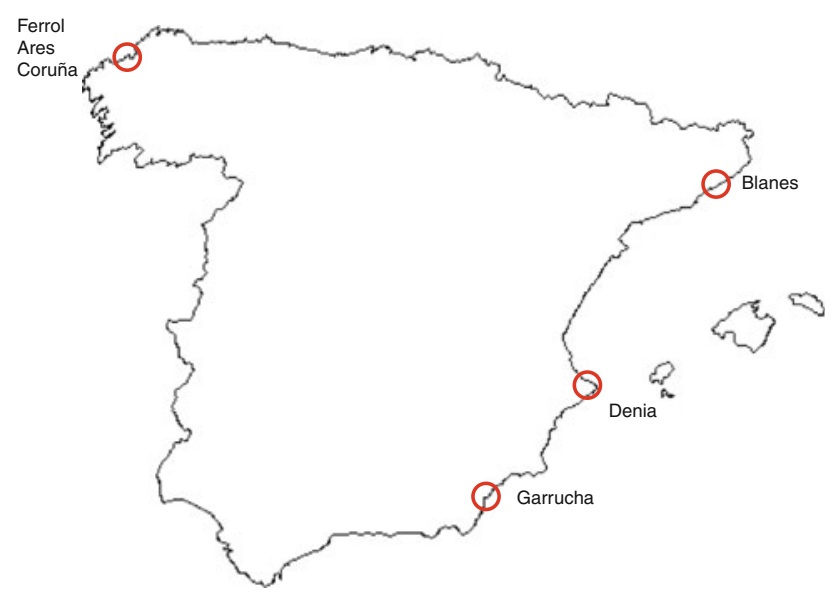

Fig. 1 Mediterranean and Atlantic sampling localities

microscope equipped with differential interference (DIC) optics. Several specimens were dehydrated through a graded series of ethanol, transferred to acetone, critical point dried, and mounted on aluminum stubs for observation and photography with a JSM 6400 JEOL scanning electron microscope.

Segment numbering follows the terminology established by Neuhaus and Higgins (2002) and applied by Sørensen and Pardos (2008). The present study revealed some inconsistencies in the literature regarding the terminology of systematic characters and their precise location along the body. In order to provide a sound basis for the present and future studies, we marked positions along longitudinal lines or bands on the trunk where taxonomically important cuticular characters usually appear in homalorhagids. These additions to the terminology are in agreement with the corresponding terminology established by Pardos et al. (1998) for cyclorhagid kinorhynchs. However, anatomical differences between cyclorhagids and homalorhagids prevent in some instances the application of the same terms and positions for both groups. Furthermore, and because of the expected variability, some positions refer to longitudinal lines, more fixed and stable, and others to bands or strips, where some slight variation among species or individuals may appear. Following the emended terminology, positions in homalorhagid kinorhynchs are defined as follows (see also Fig. 2).

Dorsal series

Middorsal (MD) Line. Referres to structures located dorsal on the midpoint of the tergal plate. This is the highest elevated point on the trunk that appears triangular shaped in cross section. The position can only be observed from the dorsal side of a dorsoventrally mounted specimen.

Paradorsal (PD) Line. Referres to structures immediately adjacent to the middorsal position of the segment. The position can only be observed from the dorsal side of a dorsoventrally mounted specimen.

Subdorsal (SD) Band. Referres to structures located bilaterally on the dorsalmost $50 \%$ of the tergal area
Fig. 2 Schematic transverse section across a trunk segment of a homalorhagid kinorhynch, showing positions of cuticular characters. Lines are marked by circles. Bands are limited by dotted lines. $L D$ laterodorsal, $L V$ lateroventral, $M D$ middorsal, $M L$ midlateral, $P D$ paradorsal, $P L$ paralateral, $P V$ paraventral, $S D$ subdorsal, $V L$ ventrolateral, $V M$ ventromedial

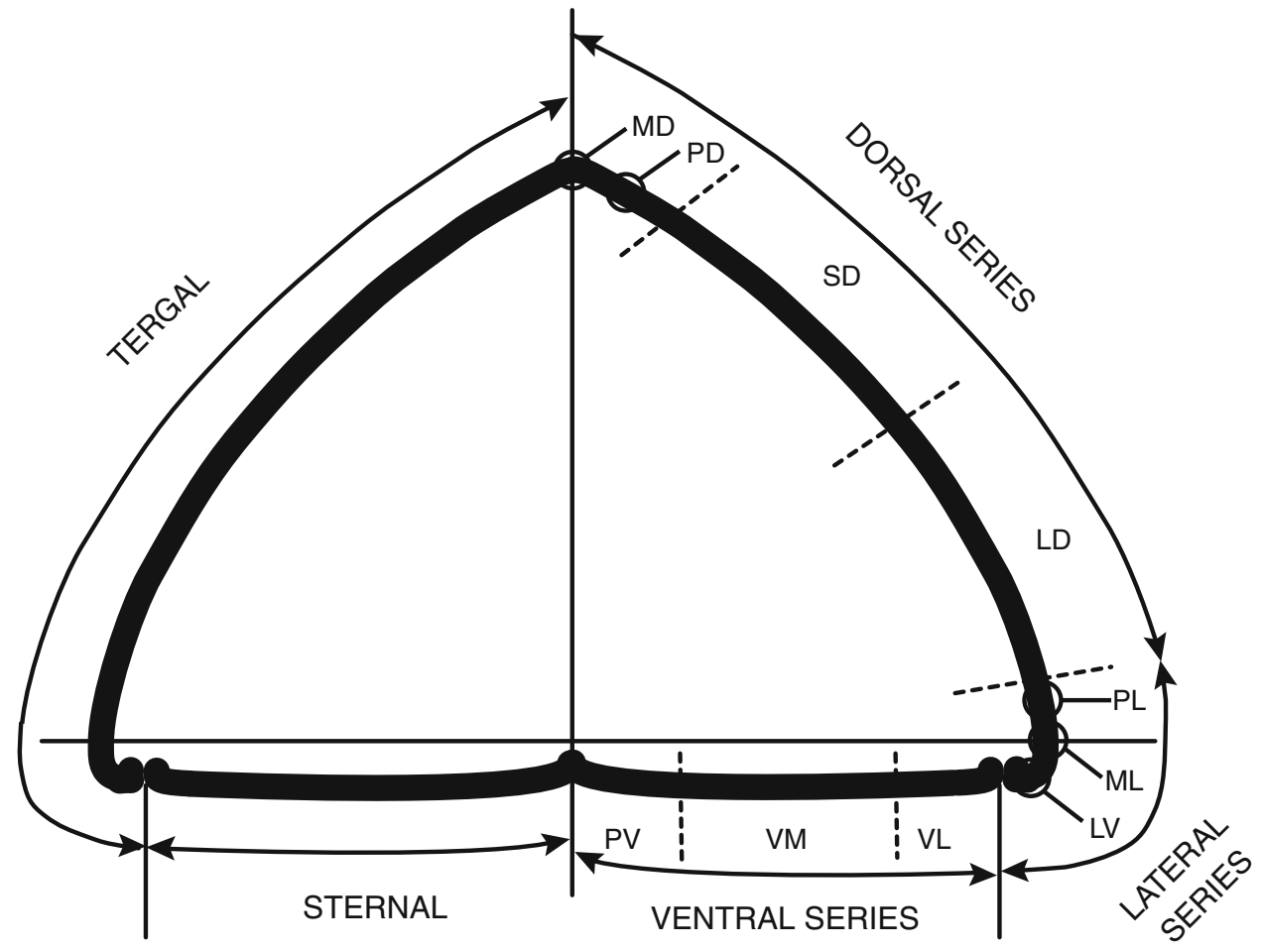


between the paradorsal position and the widest point of the trunk. The position can only be observed from the dorsal side of a dorsoventrally mounted specimen.

Laterodorsal ( $L D)$ Band. Referres to structures located bilaterally on the ventralmost $50 \%$ of the tergal area between the paradorsal position and the widest point of the trunk. The position can only be observed from the dorsal side of a dorsoventrally mounted specimen.

Positions of dorsal series are the same in both cyclorhagids and homalorhagids.

\section{Lateral series}

Paralateral (PL) Line. Referres to structures located bilaterally adjacent and dorsal to the midlateral position of the segment. The position can only be observed from the dorsal side of a dorsoventrally mounted specimen.

Midlateral $(M L)$ Line. Referres to structures located bilaterally on the tergal plate at the lateral edge of the segment, as seen from both the dorsal and ventral sides. It marks the widest point of the segment.

Lateroventral $(L V)$ Line. Referres to structures located bilaterally on the tergal plate, immediately adjacent to the tergosternal junction, as seen from the ventral side of a dorsoventrally mounted specimen.

$\mathrm{LV}$ is the ventralmost position of the lateral series in both cyclorhagids and homalorhagids. In homalorhagids, $\mathrm{PL}$ is the dorsalmost position of the series, whereas such a position does not apply to the cyclorhagid trunk shape. Hence, ML is the dorsalmost position in the lateral series of cyclorhagids, and they have in addition two positions, lateral accessory (LA) and sublateral (SL), located in between ML and LV. None of these additional positions apply to the more triangular homalorhagid trunk shape. However, cuticular structures have been detected close, but still dorsal, to the ML position (the widest point of the segment). Hence, the new position paralateral (PL) is introduced to comply with structures in this position. In our system, the PL position is related to the ML in the same way as the PD is related to the MD, or the LA is related to LV in cyclorhagids.

\section{Ventral series}

Ventrolateral ( $V L)$ Band. Referres to structures located bilaterally on the sternal plate, adjacent to the tergosternal junction. It extends over the outer longitudinal quarter of the sternal plate. The position can only be observed from the ventral side of a dorsoventrally mounted specimen.
Ventromedial (VM) Band. Referres to structures located bilaterally at or near the middle of the sternal plate, between ventrolateral and paraventral bands. The position can only be observed from the ventral side of a dorsoventrally mounted specimen.

Paraventral ( $P V)$ Band. Referres to structures located bilaterally adjacent to the midventral line of the segment. It extends over the inner quarter of the sternal plate. The position can only be observed from the ventral side of a dorsoventrally mounted specimen.

Positions of ventral series are the same in both homalorhagids and cyclorhagids.

Both the dorsal and lateral series refer to positions on the tergal plate, whereas the ventral series refers to positions on the sternal plates. In the subsequent description, the word 'pair' will refer to bilateral symmetrical structures. When two very closely positioned cuticular structures appear, they will be referred to as 'twins', having their correspondent pair of twin structures on the other side of the animal.

\section{Results}

Taxonomic account

Pycnophyes dolichurus sp. nov.

Order Homalorhagida Zelinka, 1896

Suborder Homalorhagae Zelinka, 1896

Family Pycnophyidae Zelinka, 1896

Genus Pycnophyes Zelinka, 1907

\section{Examined material}

A total of 34 specimens (18 males and 16 females) have been examined with DIC and 5 additional specimens (3 females and 2 males) with SEM. All specimens were collected in Ría de Ares, NW Spain. The type series includes the holotype, an adult female (locality: Ría de Ares, station no. 070627.3 , position $43^{\circ} 24.844^{\prime} \mathrm{N}, 008^{\circ} 17.832^{\prime} \mathrm{W}$, date 2007/06/27), the allotypic adult male (locality: Ría de Ares, station no. 080404.3 , position $43^{\circ} 25.400^{\prime} \mathrm{N}, 008^{\circ}$ $20.769^{\prime} \mathrm{W}$; date $2008 / 04 / 04$ ), and 10 additional paratypes, 5 males and 5 females from the same locality as the allotype. All types of specimens are mounted with Fluoromount- $\mathrm{G}^{\circledR}$ and deposited at the Zoological Museum, University of Copenhagen under accession numbers ZMUC KIN-430 (holotype), ZMUC KIN-431 (allotype), and ZMUC KIN432 to KIN-441 (paratypes). Additional specimens remain in the personal collection of the first author. 
Fig. 3 Pycnophyes dolichurus sp. nov. a Female, ventral view. b Female, dorsal view. c Male, ventral view of segments 10 and 11. d Male, dorsal view of segments 10 and 11 . Scale bar: $100 \mu \mathrm{m}$. esp episternal plate, ff free flap, lds laterodorsal seta, lts lateroterminal spine, lvs lateroventral seta, $m e$ middorsal elevation, $m p$ middorsal process, $m s$ muscular scar, $m s p$ midsternal plate, $m t$ anteromesial thickenings of ventral pachycycli (Mittelwülste), $p d s$ paradorsal seta, $p l s$ paralateral seta, $p s$ penile spine, $p v s$ paraventral seta, $s b s$ subcuticular structure (atria), scg subcuticular gland, $s f$ secondary fringe, ss sensory spot, $v l s$ ventrolateral seta

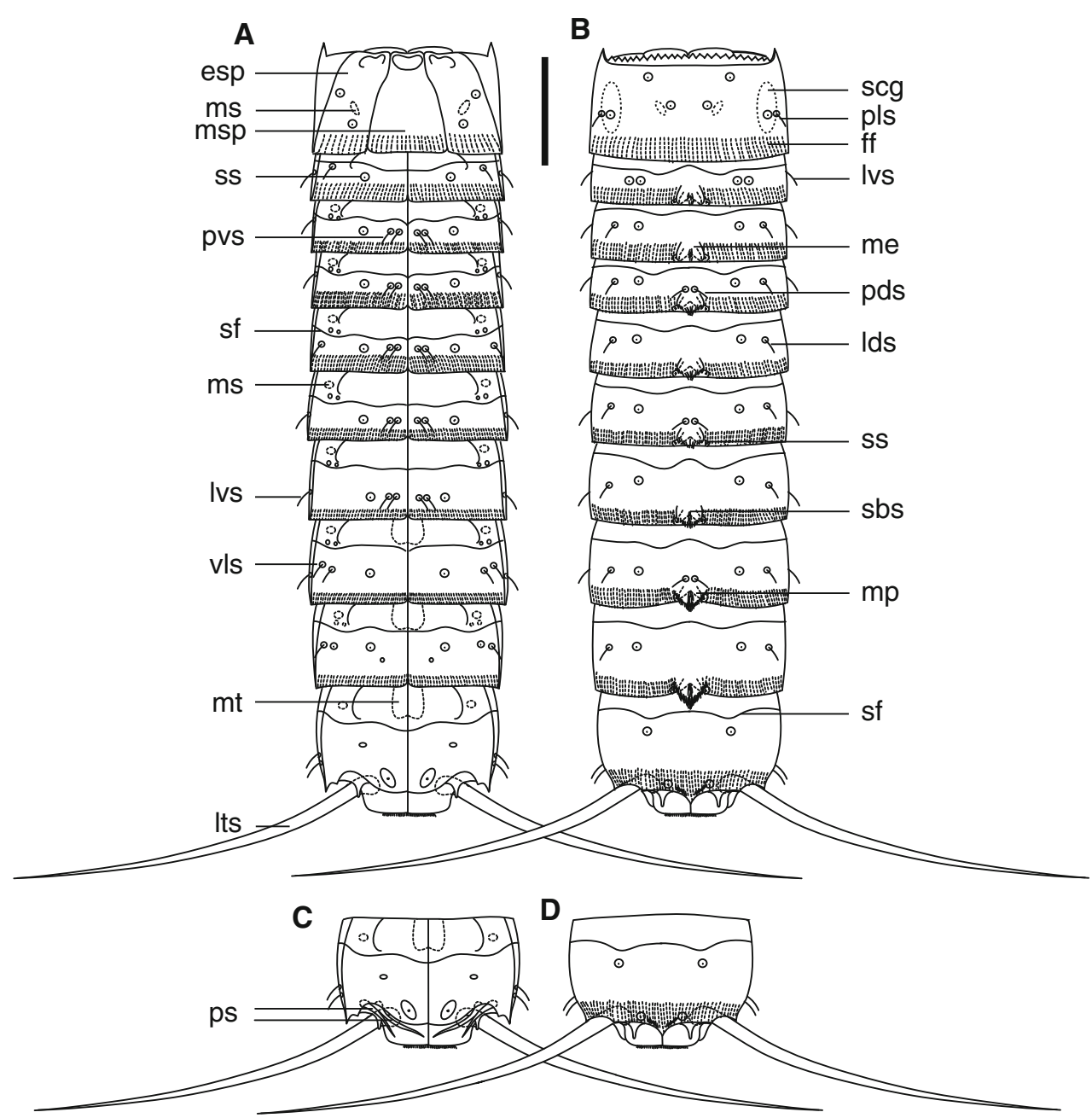

\section{Etymology}

The species name, dolichurus, is masculine, derived from Greek dolichos, long, and oura, tail, and refers to the lateral terminal spines - the longest described so far.

\section{Diagnosis}

Pycnophyes with middorsal elevations from segments 2-7 that extend into middorsal processes in segments 8 and 9 . Anterior margin of tergal plate of first trunk segment strongly denticulated. A pair of paradorsal setae on segments 4, 6, and 8 and other pair of twin paraventral setae on segments 3-7. Lateral terminal spines very long, more than $40 \%$ of trunk length. Males without big adhesive tubes on the sternal plates of the second segment (Figs. 3, 4a, b).

\section{Description}

Holotype, adult female (Fig. 3). All dimensions and measurements for the examined specimens are summarized in
Table 4. The distribution of cuticular trunk structures is summarized in Table 5.

The introvert of the specimens examined was retracted or not extended enough to allow full description.

Neck With 4 dorsal and 2 ventral placids (Fig. 5b).

Segment 1 Anterior dorsal margin of segment serrulated. Anterior lateral margins of tergal plate projecting into horn-like structures (Fig. 4e). Posterior margin forming a free flap that partially overlaps the next segment. The free flap is striated longitudinally, a feature corresponding to the "Knöpfchenreihen" of Zelinka (1928). These structures are in fact small cuticular pillars as shown with TEM by Neuhaus (1993: Fig. 13) (Fig. 5b). Minute pectinate fringe. Two episternal plates and a trapezoidal midsternal plate (Fig. 5a). Episternal plates with sensory spots in ventromedial and ventrolateral positions, and with a muscle scar in ventromedial position. Tergal plate with three pairs of sensory spots (two subdorsal and one laterodorsal pairs), one pair of paralateral setae adjacent to the laterodorsal sensory spot (Figs. 3, 4e), and one pair of subdorsal 
Fig. 4 Pycnophyes dolichurus sp. nov., SEM photographs. a Male, ventral view. b Male, dorsal view. c Female; detail of segment 7 showing middorsal elevation near posterior segment margin. d Male; detail of segment 9 showing middorsal process near posterior segment margin. e Male; detail of anterolateral part of tergal plate of segment 1 . f Male; segments $3-7$, ventral view. $h p$ horn-like protrusion, lvs lateroventral seta, me middorsal elevation, $m p$ middorsal process, pls paralateral seta, pvs paraventral seta, $s f$ secondary fringe, $s s$ sensory spot, $v l s$ ventrolateral seta
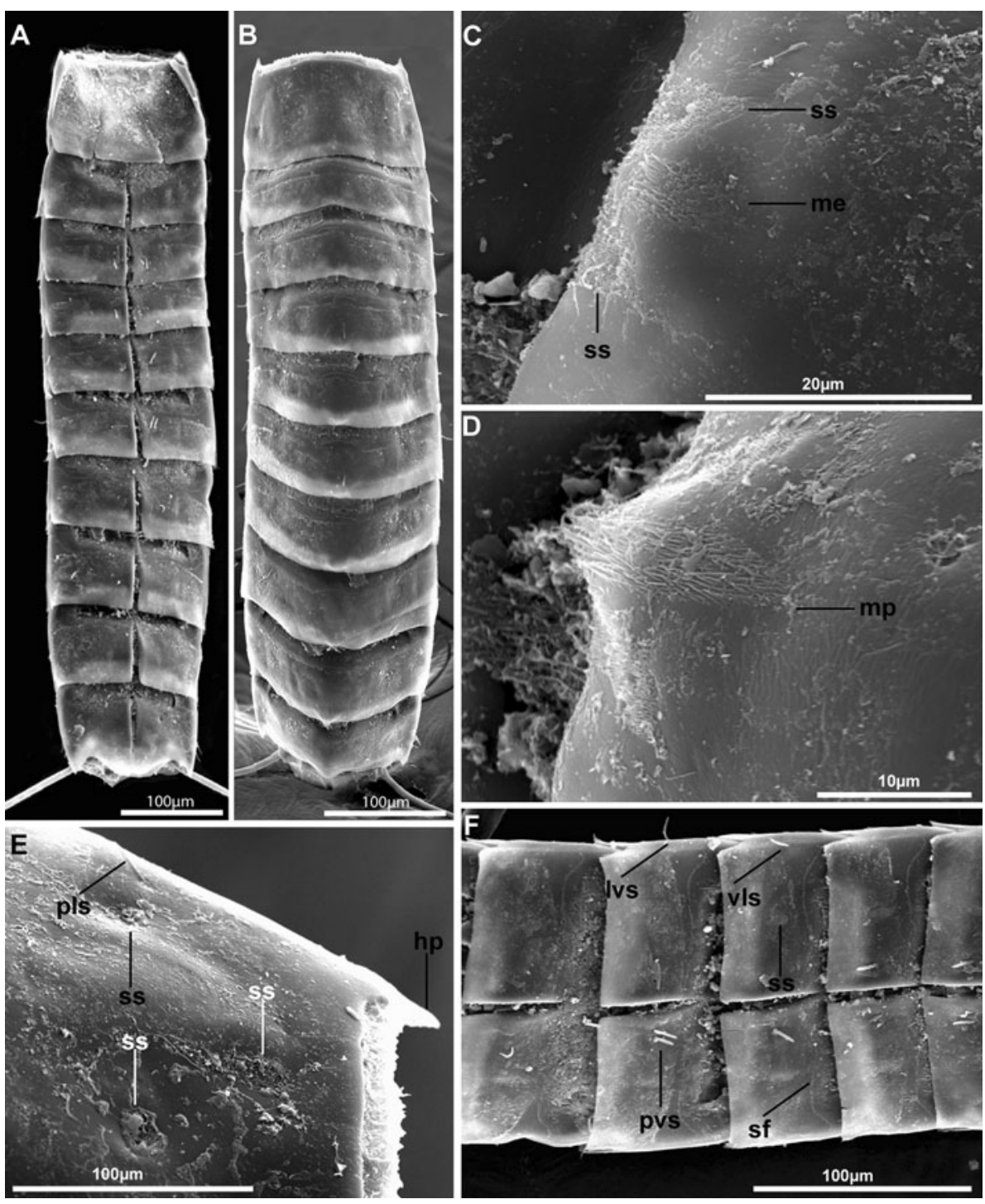

muscular scars. Segments furthermore with one pair of subcuticular glands (Fig. 5b).

Segment 2 Pachycycli of tergal and sternal plates well developed. Conspicuous secondary fringe of tiny, denticulated cuticular hairs all around the segment. Sternal plates with a pair of ventromedial sensory spots and a pair of ventrolateral setae (Fig. 5c). One pair of longitudinal, ventrolateral muscular scars anterior to the secondary fringe. Tergal plate with smooth posterior margin showing a hairy middorsal elevation, not protruding beyond the segment margin. One pair of paradorsal sensory spots near posterior margin. Prominent paradorsal butterfly-like structures that correspond to subcuticular atria of sensory spots, only visible with DIC optics. One pair of subdorsal twin sensory spots and one pair of lateroventral setae. Males always without paired adhesive tubes that otherwise typically are found on the second segment of the sternal plates in species of Pycnophyes.

Segment 3 Sternal plates with a pair of paraventral twin setae and a pair of ventromedial sensory spots (Figs. 4f, $5 \mathrm{c})$. The position of the paraventral twin setae is very consistent in the studied specimens. The only observed variation was displayed as a slight displacement of one of the twin setae in a few specimens. This kind of variation may appear at any segment. Tergal plate with a middorsal elevation, one pair of paradorsal sensory spots near posterior margin with their associated subcuticular atria, one pair of subdorsal sensory spots, one pair of laterodorsal setae, and one pair of lateroventral setae. Secondary fringe similar to fringe on segment 2. One pair of longitudinal ventrolateral muscular scars present anterior to the secondary fringe. 
Table 4 Pycnophyes dolichurus sp. nov. Measurements $(\mu \mathrm{m})$ for holotype and means of studied specimens, females and males

\begin{tabular}{|c|c|c|c|c|c|c|}
\hline Character & Holotype & $n$ & Range & Mean & SD & $\mathrm{SD} \stackrel{+}{+}-\widehat{\jmath}$ \\
\hline \multirow[t]{2}{*}{ TL } & \multirow[t]{2}{*}{715} & †10 & $649-746$ & 9699 & †35.87 & \multirow[t]{2}{*}{39.11} \\
\hline & & 34 & $3660-769$ & ऽ7707 & 350.64 & \\
\hline MSW-6 & 186 & q1 & - & - & - & - \\
\hline SW-10 & 151 & †1 & - & - & - & \\
\hline \multirow[t]{2}{*}{ SL1 } & \multirow[t]{2}{*}{90} & $q 10$ & +84-96 & †90 & $\uparrow 3.10$ & \multirow[t]{2}{*}{3.20} \\
\hline & & 34 & 386-93 & †90 & 73.96 & \\
\hline \multirow[t]{2}{*}{ SL2 } & \multirow[t]{2}{*}{58} & q10 & +49-63 & ○58 & †3.68 & \multirow[t]{2}{*}{3.36} \\
\hline & & 34 & 352-60 & ¿157 & 33.47 & \\
\hline \multirow[t]{2}{*}{ SL3 } & \multirow[t]{2}{*}{54} & q10 & †54-70 & 964 & $\uparrow 4.19$ & \multirow[t]{2}{*}{3.80} \\
\hline & & 34 & ऽ58-63 & 360 & 33.12 & \\
\hline \multirow[t]{2}{*}{ SL4 } & \multirow[t]{2}{*}{64} & q10 & †59-72 & 967 & 94.81 & \multirow[t]{2}{*}{3.90} \\
\hline & & 34 & $361-66$ & 364 & ô1.74 & \\
\hline \multirow[t]{2}{*}{ SL5 } & \multirow[t]{2}{*}{69} & †10 & $q 65-76$ & $\$ 70$ & †7.83 & \multirow[t]{2}{*}{7.07} \\
\hline & & 34 & $361-68$ & 365 & 33.64 & \\
\hline \multirow[t]{2}{*}{ SL6 } & \multirow[t]{2}{*}{74} & q10 & $968-79$ & $\$ 75$ & $\uparrow 3.98$ & \multirow[t]{2}{*}{4.94} \\
\hline & & 34 & $364-74$ & 368 & 36.38 & \\
\hline \multirow[t]{2}{*}{ SL7 } & \multirow[t]{2}{*}{75} & $q 10$ & ๆ75-81 & †78 & †2.00 & \multirow[t]{2}{*}{3.04} \\
\hline & & 34 & 369-80 & 374 & 33.89 & \\
\hline \multirow[t]{2}{*}{ SL8 } & \multirow[t]{2}{*}{84} & q10 & †81-88 & †84 & $\uparrow 2.64$ & \multirow[t]{2}{*}{2.83} \\
\hline & & 34 & 378-87 & 382 & 33.26 & \\
\hline \multirow[t]{2}{*}{ SL9 } & \multirow[t]{2}{*}{88} & q10 & ๆ81-93 & †88 & $\uparrow 4.13$ & \multirow[t]{2}{*}{3.93} \\
\hline & & 34 & 381-94 & 387 & 37.49 & \\
\hline SL10 & 92 & q10 & +89-99 & +96 & $\uparrow 3.59$ & 3.87 \\
\hline & & 34 & \$86-99 & 393 & 15.48 & \\
\hline SL11 & 55 & q10 & q38-55 & $\uparrow 44$ & +18.29 & 15.55 \\
\hline & & 34 & 343-50 & 347 & 33.51 & \\
\hline LTS & 320 & $q 10$ & $+286-332$ & †315 & +13.82 & 23.43 \\
\hline & & 33 & శ243-317 & ð288 & \$39.83 & \\
\hline$\% \mathrm{LTS} / \mathrm{TL}$ & $45 \%$ & $q 10$ & †41-48\% & +45\% & $\uparrow 0.02$ & 0.05 \\
\hline & & 33 & 万32-49\% & 万ิ $42 \%$ & Ј0.09 & \\
\hline
\end{tabular}

LTS lateroterminal spine, MSW-6 maximum sternal width (on segment 6), $n$ number of measured specimens, $S D$ standard deviation, $S L$ segment length, $S W-10$ standard width (on segment 10), $T L$ total length, of female, ô male

Segment 4 Tergal and sternal plates same as those on segment 3 but with one pair of paradorsal setae flanking the middorsal elevation. Secondary fringe similar to fringe on segment 2. One pair of longitudinal ventrolateral muscular scars anterior to the secondary fringe.

Segment 5 Sternal plates similar to those on segment 3 except for the presence of a pair of ventrolateral setae (Fig. 4f). Tergal plate same as on segment 3 except for the absence of lateroventral setae. Secondary fringe similar to fringe on segment 2. One pair of longitudinal ventrolateral muscular scars present anterior to the secondary fringe.

Segment 6 Sternal plates same as on segment 3. Tergal plate same as on segment 4 except for the laterodorsal setae
Table 5 Summary of location of setae and sensory spots in Pycnophyes dolichurus sp. nov. arranged by series

\begin{tabular}{lllllllll}
\hline Segment & PD & SD & LD & PL & LV & VL & VM & PV \\
\hline 1 & & ss, ss & ss & se & & ss & ss & \\
2 & ss & tss & & & se & se & ss & \\
3 & ss & ss & se & & se & & ss & tse \\
4 & se, ss & ss & se & & se & & ss & tse \\
5 & ss & ss & se & & & se & ss & tse \\
6 & se, ss & ss & se & se & & ss & tse \\
7 & ss & ss & se & se & & ss & tse \\
8 & se, ss & ss & se & & se & tse & ss & \\
9 & ss & ss & se & & & se, ss & ss & \\
10 & ss & ss & & & tse & & & ss \\
11 & & & & & lts & ps $(2, m)$ & &
\end{tabular}

$L D$ laterodorsal, $L V$ lateroventral, $P D$ paradorsal, $P L$ paralateral, $P V$ paraventral, $S D$ subdorsal, $V L$ ventrolateral, $V M$ ventromedial

$m$ male condition of sexually dimorphic character, lts lateroterminal spine, $p s$ penile spine, se seta, ss sensory spot, tse twin setae, tss twin sensory spots

that are situated slightly more laterally. Secondary fringe similar to fringe on segment 2. One pair of longitudinal ventrolateral muscular scars present anterior to the secondary fringe.

Segment 7 Sternal plates same as on segment 3. Tergal plate similar to plate on segment 6 , except for the absence of paradorsal setae flanking the middorsal elevation (Fig. 4c). Secondary fringe similar to fringe on segment 2. One pair of longitudinal ventrolateral muscular scars present anterior to the secondary fringe.

Segment 8 Sternal plates without paraventral setae. Segment with a pair of ventromedial sensory spots and one pair of ventrolateral twin setae. The presence of ventrolateral twin setae is very consistent in the animals studied; however, a little variation regarding the relative position of the two setae can be detected in different specimens. Midventral thickenings of ventral pachycycli (Mittelwülste) present near anteromesial margin of segment. Tergal plate same as on segment 6 . The middorsal process protruding beyond the segment margin appears bigger and more pointed than the corresponding structures of preceding segments (Fig. 5d). Secondary fringe similar to fringe on segment 2. One pair of longitudinal ventrolateral muscular scars anterior present to the secondary fringe.

Segment 9 Sternal plates without paraventral setae. Sternal plates with pair of ventromedial and ventrolateral sensory spots. The latter is located in twin positions with a pair of ventrolateral setae. Midventral thickenings of ventral pachycycli (Mittelwülste) present near anteromesial margin of segment. One pair of muscular scars, visible only with LM, present in paraventral position. Tergal plate same 
Fig. 5 Pycnophyes dolichurus sp. nov., interference contrast (DIC) photographs. a Paratype, female; head and segments 1-2, ventral view. b Paratype, female; segment 1, dorsal view. c Paratype, female; segments 2-3, ventral view. d Paratype, female; segment 8 , dorsal view. e Allotype, male; segments 9-11, ventral view. f Paratype, female; segments 9-10, dorsal view. Abbreviations: esp episternal plate, $f f$ free flap, in introvert, $l d s$ laterodorsal seta, lts lateroterminal spine,

lvs lateroventral seta, $m c$ mouth cone, msp midsternal plate, $m t$ anteromesial thickenings of ventral pachycycli (Mittelwülste), pvs paraventral seta, $s b s$ subcuticular structure (atria), scg subcuticular gland, ss sensory spot, $v l s$ ventrolateral seta
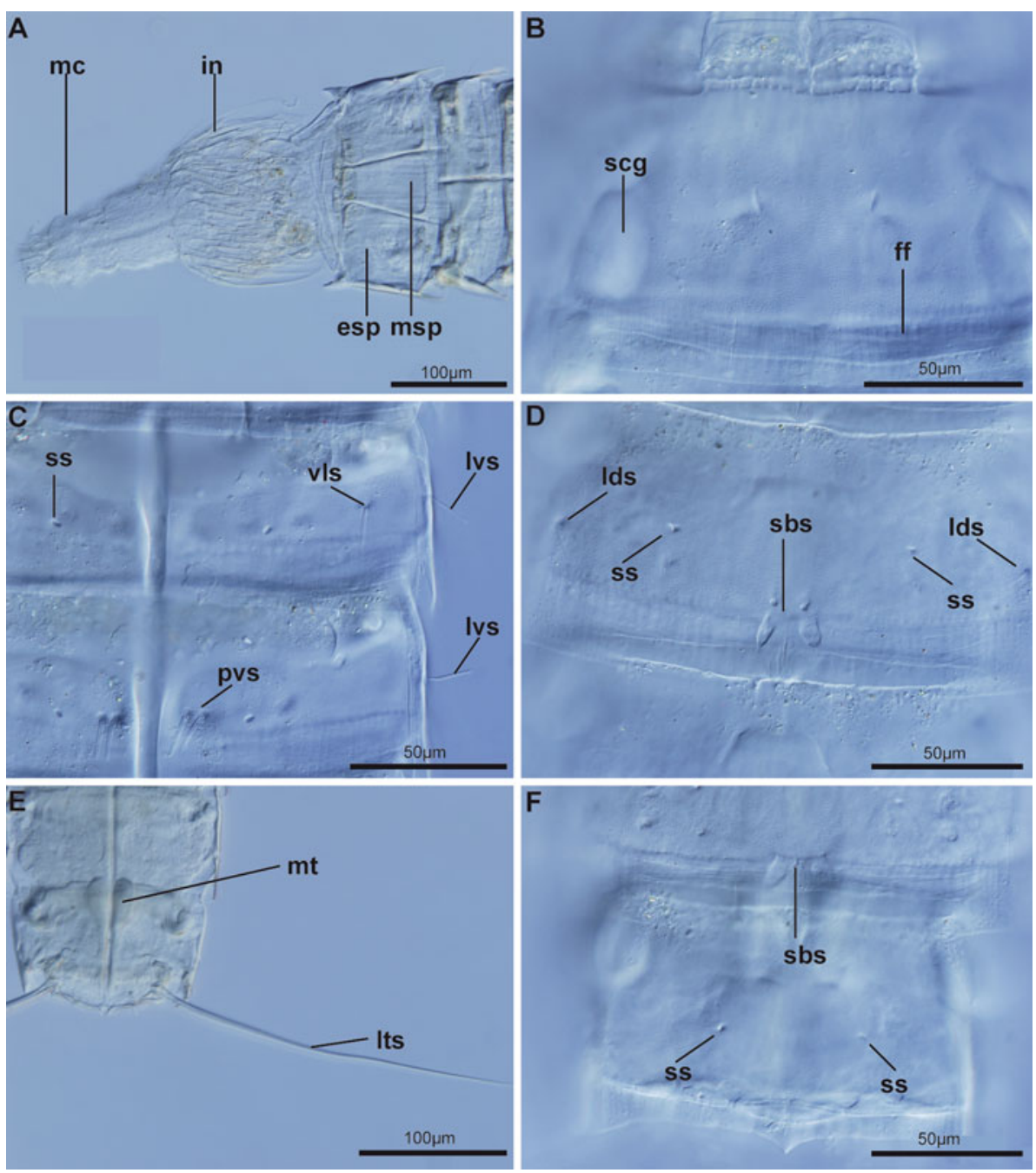

as on segment 7 , except for the absence of lateroventral setae and the presence of a protruding middorsal process that appears more developed and pointed than on segment 8 (Fig. 4d). Secondary fringe similar to fringe on segment 2. One pair of longitudinal ventrolateral muscular scars present anterior to the secondary fringe.

Segment 10 Sternal plates with a pair of paraventral sensory spots near the posterior margin of segment. Midventral thickenings of ventral pachycycli (Mittelwülste) present near anteromesial margin of segment (Fig. 5c). Tergal plate with one pair of subdorsal sensory spots and one pair of twin lateroventral setae. Laterodorsal setae not present. Posterior margin pointed but without middorsal elevation and with a pair of paradorsal sensory spots (Fig. 5f). Secondary fringe similar to fringe on segment 2. One pair of longitudinal ventrolateral muscular scars anterior to the secondary fringe.

Segment 11 Lateral terminal spines very long, almost half of the trunk length (Fig. 5e). Males with two pairs of penile spines near anterior segment margin (Fig. 3c).
Taxonomic account

Pycnophyes aulacodes sp. nov.

Order Homalorhagida Zelinka, 1896

Suborder Homalorhagae Zelinka, 1896

Family Pycnophyidae Zelinka, 1896

Genus Pycnophyes Zelinka, 1907

\section{Examined material}

A total of 36 specimens (14 males and 22 females) were examined with DIC and 6 additional specimens $(3$ males and 3 females) with SEM. The specimens were collected in Ría de Ares and Ría de La Coruña, NW Spain; Blanes, NE Spain and Garrucha and Denia, E Spain. The type series includes the holotypic adult female (locality: Ría de Ares, station no. 070627.1 , position: $43^{\circ} 25.064^{\prime} \mathrm{N}, 008^{\circ}$ $16.558^{\prime} \mathrm{W}$, date 2007/06/27), allotypic adult male (locality: Ría de Ares, station no. 080404.3; position: $43^{\circ} 25.400^{\prime} \mathrm{N}$, 
A
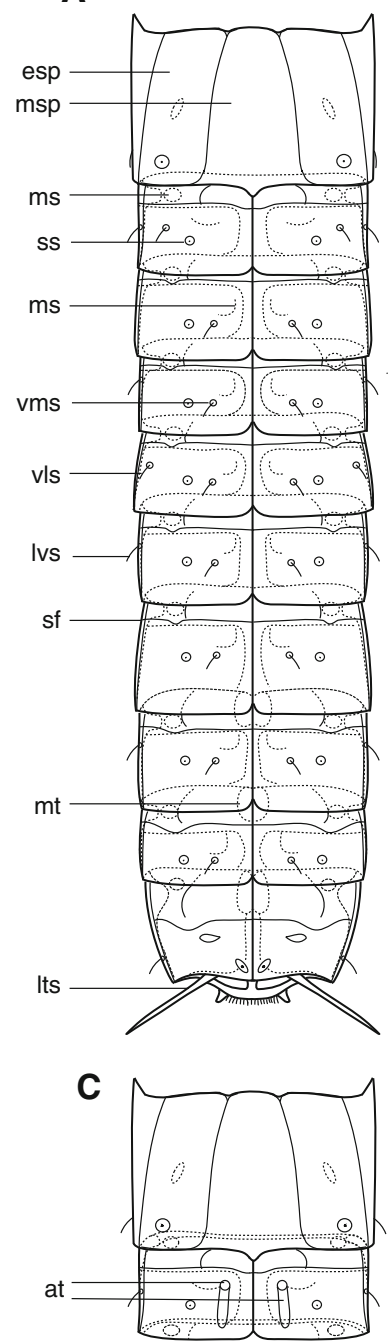

B

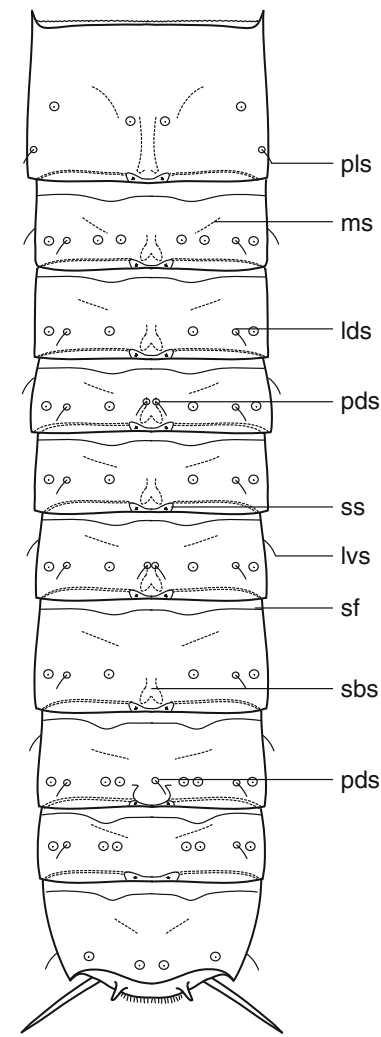

D

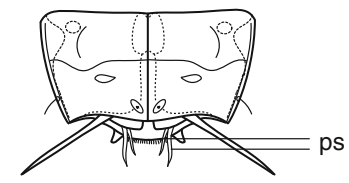

Fig. 6 Pycnophyes aulacodes sp. nov. a Female, ventral view. b Female, dorsal view. c Male, ventral view of segments 1 and 2 . d Male, ventral view of segments 10 and 11. Scale bar: $100 \mu \mathrm{m}$. Abbreviations: at adhesive tube, esp episternal plate, lds laterodorsal seta, lts lateroterminal spine, lvs lateroventral seta, $m d s$ middorsal seta, $m s$ muscular scar, $m s p$ midsternal plate, $m t$ anteromesial thickenings of ventral pachycycli (Mittelwülste), $p d s$ paradorsal seta, $p l s$ paralateral seta, $p s$ penile spine, sbs subcuticular structure (atria), $s f$ secondary fringe, ss sensory spot, $v l s$ ventrolateral seta, $v m s$ ventromedial seta

$008^{\circ} 20.769^{\prime} \mathrm{W}$; date $\left.2008 / 04 / 04\right)$, and 10 paratypes, 5 males and 5 females from the same locality as the holotype. All types of specimens are mounted in Fluoromount- $G^{\circledR}$ and deposited at the Zoological Museum, University of Copenhagen under accession numbers ZMUC KIN-442 (holotype), ZMUC KIN-443 (allotype), and ZMUC KIN444 to KIN-453 (paratypes). Additional specimens remain in the personal collection of the first author.

Table 6 Pycnophyes aulacodes sp. nov. Measurements $(\mu \mathrm{m})$ for holotype and means of studied specimens, females and males

\begin{tabular}{|c|c|c|c|c|c|c|}
\hline Character & Holotype & $n$ & Range & Mean & SD & $\mathrm{SD}_{+}-\widehat{\jmath}$ \\
\hline \multirow[t]{2}{*}{$\mathrm{TL}$} & \multirow[t]{2}{*}{713} & +6 & +662-806 & †736 & †53.01 & \multirow[t]{2}{*}{47.04} \\
\hline & & 35 & 3727-808 & 3775 & Љ30.70 & \\
\hline MSW-7 & 171 & q1 & - & - & - & \multirow[t]{2}{*}{-} \\
\hline SW-10 & 168 & q1 & - & - & - & \\
\hline \multirow[t]{2}{*}{ SL1 } & \multirow[t]{2}{*}{112} & +6 & +97-115 & q10 & +6.95 & 6.63 \\
\hline & & 35 & ô107-120 & ○113 & 6.52 & \\
\hline \multirow[t]{2}{*}{ SL2 } & \multirow[t]{2}{*}{71} & 96 & + $48-72$ & $q 65$ & +8.67 & \multirow[t]{2}{*}{7.84} \\
\hline & & 35 & $766-79$ & 372 & 5.22 & \\
\hline \multirow[t]{2}{*}{ SL3 } & \multirow[t]{2}{*}{74} & 96 & $960-77$ & $\$ 70$ & $\$ 5.95$ & \multirow[t]{2}{*}{5.38} \\
\hline & & 35 & 370-79 & 375 & 33.93 & \\
\hline \multirow[t]{2}{*}{ SL4 } & \multirow[t]{2}{*}{75} & 96 & $966-76$ & $\$ 73$ & $\$ 3.76$ & \multirow[t]{2}{*}{4.62} \\
\hline & & 35 & 366-79 & 372 & 35.93 & \\
\hline \multirow[t]{2}{*}{ SL5 } & \multirow[t]{2}{*}{76} & 96 & $967-76$ & $\$ 74$ & $\bigcirc 3.54$ & \multirow[t]{2}{*}{5.25} \\
\hline & & 35 & $368-79$ & 376 & 37.10 & \\
\hline \multirow[t]{2}{*}{ SL6 } & \multirow[t]{2}{*}{79} & 96 & +70-87 & $\$ 79$ & $\circ 5.67$ & \multirow[t]{2}{*}{4.97} \\
\hline & & 35 & 3775-87 & 380 & 34.64 & \\
\hline \multirow[t]{2}{*}{ SL7 } & \multirow[t]{2}{*}{85} & 96 & †71-92 & ○82 & $\$ 7.10$ & \multirow[t]{2}{*}{6.68} \\
\hline & & 35 & 376-92 & 384 & 6.72 & \\
\hline \multirow[t]{2}{*}{ SL8 } & \multirow[t]{2}{*}{87} & 96 & ○75-88 & ○83 & +4.60 & \multirow[t]{2}{*}{4.45} \\
\hline & & 35 & 383-92 & 387 & 33.36 & \\
\hline \multirow[t]{2}{*}{ SL9 } & \multirow[t]{2}{*}{86} & 96 & †72-87 & ○83 & +5.65 & \multirow[t]{2}{*}{5.12} \\
\hline & & 35 & 384-90 & 388 & 32.58 & \\
\hline SL10 & 85 & $\bigcirc 4$ & 甲83-100 & †91 & $\bigcirc 7.75$ & 5.36 \\
\hline & & 35 & 388-96 & 392 & హ3.41 & \\
\hline SL11 & 17 & q1 & - & †17 & - & - \\
\hline & & $\widehat{\jmath} 0$ & - & & - & \\
\hline LTS & 74 & +6 & †74-93 & †80 & +6.57 & 7.28 \\
\hline & & 33 & 786-89 & 382 & ऽ̋10.05 & \\
\hline$\% \mathrm{LTS} / \mathrm{TL}$ & $10 \%$ & +6 & $+10-12 \%$ & +11\% & +0.01 & 0.01 \\
\hline & & 33 & 39-11\% & ○ै10\% & ठే 0.01 & \\
\hline
\end{tabular}

LTS lateroterminal spine, MSW-7 maximum sternal width (on segment 7), $n$ number of measured specimens, $S D$ standard deviation, $S L$ segment length, $S W-10$ standard width (on segment 10), $T L$ total length, ㅇ female, ô male

\section{Etymology}

The species name, aulacodes, is masculine, derived from Greek aulakodes, meaning "furrowlike", and refers to the prominent and slit-like subdorsal muscular scars.

\section{Diagnosis}

Pycnophyes with middorsal elevations present on segments 1-9. Paradorsal setae present on segments 4 and 6. Tergal anterior margin of segment 1 finely denticulated. Without lateroventral setae on segments 3, 5, 7, and 9. Conspicuous 
Table 7 Summary of location of setae and sensory spots in Pycnophyes aulacodes sp. nov

\begin{tabular}{lllllllll}
\hline Segment & PD & SD & LD & PL & LV & VL & VM & PV \\
\hline 1 & ss, ss & & ss & se & & ss & \\
2 & ss & tss & se, ss & & se & se(f) & ss, at(m) \\
3 & ss & ss & se, ss & & & & se, ss \\
4 & se, ss & ss & se, ss & & se & & se, ss \\
5 & ss & ss & se, ss & & & se & se, ss \\
6 & se, ss & ss & se, ss & & se & & se, ss \\
7 & ss & ss & se, ss & & & & se, ss \\
8 & se(1), ss & tss & se, ss & & se & & se, ss \\
9 & ss & tss & se, ss & & & & se, ss & \\
10 & ss & & ss & & se & & & ss \\
11 & & & & & lts & ps $(2, \mathrm{~m})$ & & \\
\hline
\end{tabular}

$L D$ laterodorsal, $L V$ lateroventral, $P D$ paradorsal, $P L$ paralateral, $P V$ paraventral, $S D$ subdorsal, $V L$ ventrolateral, $V M$ ventromedial

at adhesive tube, $f$ female condition of sexually dimorphic character, lts lateroterminal spine, $m$ male condition of sexually dimorphic character, se seta, ss sensory spot, tss twin sensory spots, (1) only one unpaired cuticular structure oblique, groove-like muscular scars in the subdorsal position, and crescentic muscular scars in the paraventral position present on all segments (Figs. 6, 8 b-f).

\section{Description}

Holotype, adult female. All dimensions and measurements of the examined specimens are summarized in Table 6 . The distribution of cuticular trunk structures is summarized in Table 7.

Neck Placids could not be observed.

Segment 1 Anterior margin of tergal plate serrated. Lateral margins of tergal plate extend into horn-like structures. The posterior dorsal segment margin free, covering the anterior edge of the following segment and overlaps some mucous gland openings (Fig. 7e). This area often appears filled with a mixture of mucus and organic debris, a picture repeated for all trunk segments. Pectinate fringe inconspicuous in the dorsal region but more developed in the
Fig. 7 Pycnophyes aulacodes sp. nov., SEM photographs. a Male, ventral view. b Male, dorsal view. c Female; detail showing middorsal position on segments 2-3. d Male; segment 5 , detail of ventromedial position on left sternal plate. e Male; segments 4-7, dorsal view. f Male; segment 1-2, ventral view. at adhesive tube, go gland opening, me middorsal elevation, $p p$ pointed projection, $s f$ secondary fringe, $s s$ sensory spot, vms ventromedial seta
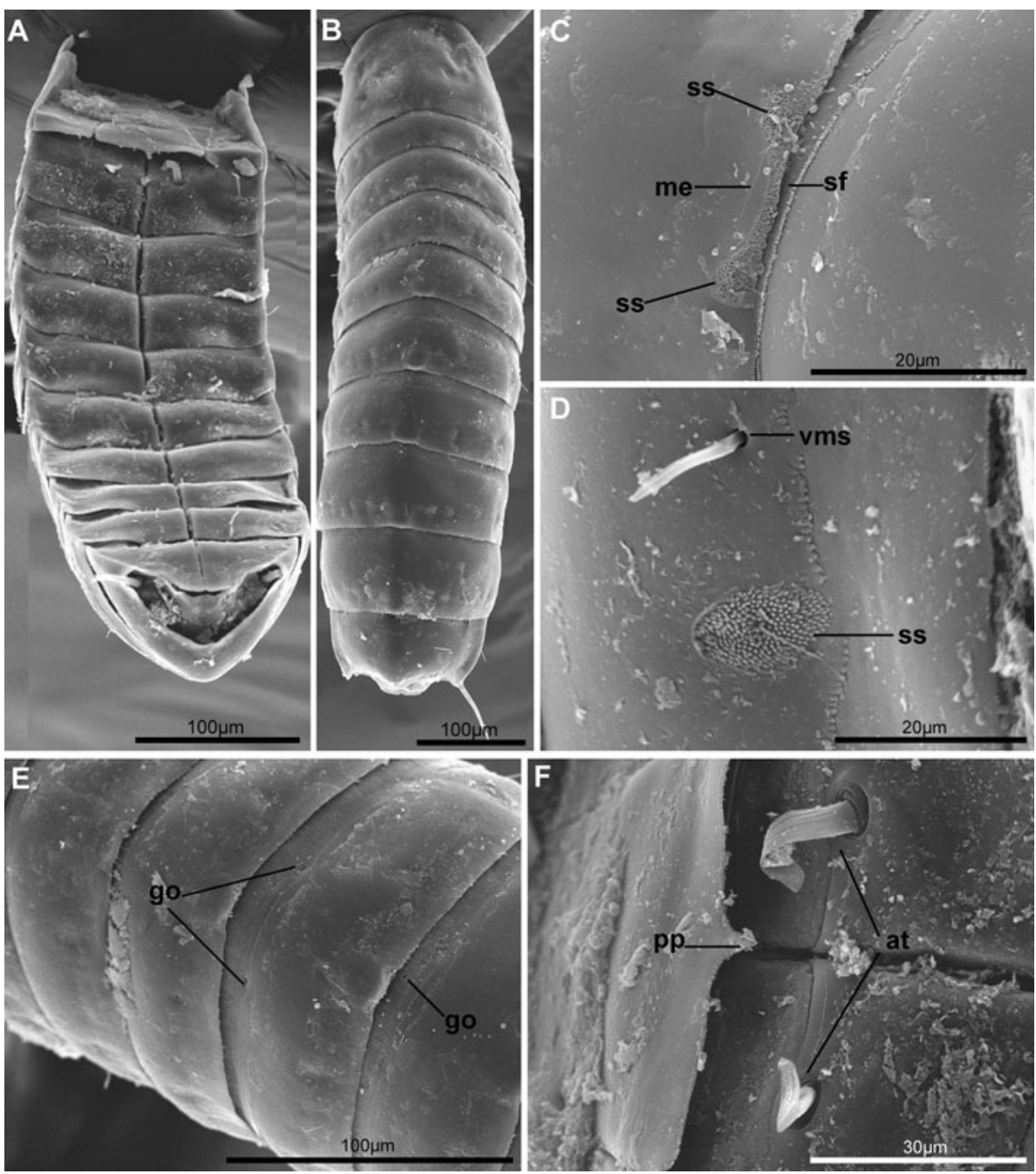
Fig. 8 Pycnophyes aulacodes, sp. nov., interference contrast (DIC) photographs. a Allotype, male; segments 1-5, dorsal view. b Paratype, male; segments 2-3, ventral view. c Paratype, female; segments 1-4, dorsal view. d Holotype, female; right sternal plates of segments 7-8, ventral view. e Paratype, male; segments 7-11, ventral view. f Paratype, male; segments 10-11, ventral view. at adhesive tube, lts lateroterminal spine, $l v s$ lateroventral seta, $m s$ muscular scar, $p p$ pointed projection, $p s$ penile spine, $s b s$ subcuticular structure (atria), $s f$ secondary fringe, vms ventromedial seta
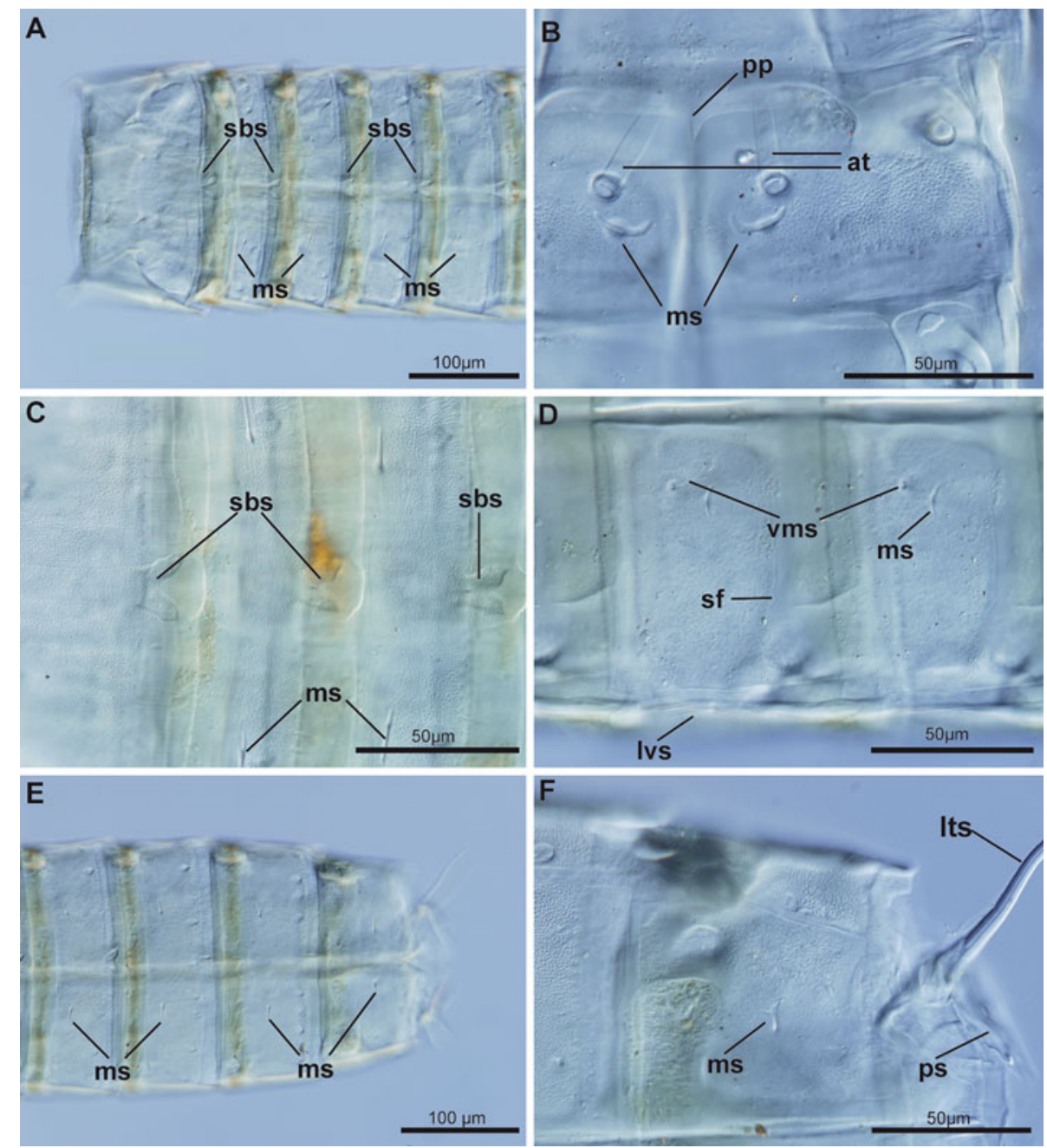

ventral region. Ventral side with two episternal plates and a trapezoidal midsternal plate. The midsternal plate shows a midventral, pointed, posteriorly orientated projection (Figs. 7f, 8b). Each episternal plate with a conspicuous ventrolateral sensory spot near the posterior margin and a ventromedial muscular scar in the middle region of plate. Tergal plate with a pair of paralateral setae and two pairs of sensory spots, one paradorsal and near the groove-like muscular scars and one laterodorsal pair. Additionally, there is a small middorsal elevation that never surpasses the posterior margin of the segment, with a pair of paradorsal sensory spots near its posterior margin. Prominent paradorsal butterfly-like structures that correspond to subcuticular atria of sensory spots, only visible with DIC optics (Fig. 8a, c).

Segment 2 Sternal plates with a pair of crescentic paraventral muscular scars and a pair of ventromedial sensory spots (Fig. 8b). Females furthermore with a pair of ventrolateral setae. Pectinate fringe strongly reduced, only visible with SEM. Tergal plate with a pair of lateroventral and laterodorsal setae. Subdorsal twin sensory spots and one pair of laterodorsal sensory spots close to the laterodorsal setae are present. Middorsal elevation with a pair of paradorsal, marginal sensory spots (Fig. 8c). Subcuticular structure similar to the one on segment 1 . A pair of subdorsal groove-like, oblique muscular scars (Fig. 8c) is present. Males always with one pair of big, adhesive tubes located ventromedially on the sternal plates (Fig. 6c). Secondary fringe near anterior margin, parallel to the segment edge with two subdorsal and two ventromedial indentations (Fig. 8b).

Segment 3 Sternal plates with a pair of paraventral crescentic muscular scars and a pair of ventromedial setae near more lateral sensory spot (Fig. 8b). Tergal plate with middorsal elevation and associated structures similar to those on segment 2, a pair of subdorsal groove-like muscular scars, a pair of laterodorsal setae, and a pair of sensory spots in paradorsal, subdorsal, and laterodorsal positions. Secondary fringe same as fringe on segment 2 (Fig. 7c). 
Segment 4 Tergal and sternal plates same as on segment 3 , except for the presence of a pair of paradorsal setae in the middorsal elevation and a pair of lateroventral setae. Secondary fringe as fringe on segment 3 .

Segment 5 Sternal plates similar to those on segment 3 except for the presence of a pair of ventrolateral setae. Tergal plate same as on segment 3 (Fig. 7d).

Segment 6 Sternal and tergal plates same as those on segment 4.

Segment 7 Sternal and tergal plates same as those on segment 3 (Fig. 8d, e).

Segment 8 Sternal plates same as those on segment 3. One pair of anteromesial thickenings of ventral pachycycli (Mittelwülste) present near anterior segment margin. Tergal plate same as on segment 2 except for the presence of an unpaired paradorsal seta in the right side of middorsal elevation. Middorsal elevation wider than those on the previous segments.

Segment 9 Sternal plates same as those on segment 3, but in addition with one pair of anteromesial thickenings of ventral pachycycli (Mittelwülste) near anterior margin of segment. Tergal plate same as on segment 8 but without lateroventral and paradorsal setae. Middorsal elevation even wider and less conspicuous than the one on the previous segment.

Segment 10 Sternal plates with a pair of droplet-shaped muscular scars and a pair of paraventral sensory spots near the posterior segment margin (Fig. 8f). Anteromesial thickenings of ventral pachycycli (Mittelwülste) present near anterior margin. Tergal plate with a pair of groovelike muscular scars, a pair of paradorsal and laterodorsal sensory spots, and a pair of lateroventral setae. Middorsal elevation not present.

Segment 11 With lateral terminal spines. Males with two pairs of penile spines (Figs. 6d, 8f).

\section{Discussion}

\section{Taxonomy}

A commonly used diagnostic trait for species of the genus Pycnophyes is the presence and appearance of the middorsal-(Higgins 1983) or spinose processes, following the terminology established by Higgins (1983) and summarized by Sørensen and Pardos (2008). The middorsal process is a longitudinal, keel-like protruding edge located in the middorsal line of the segment. It may or may not surpass the posterior margin of the segment and hence form a free tip. Two types are usually recognized: obtuse/rounded ones or pointed/horned ones. The two types are not easily distinguished from each other in practice. Here, we identify the obtuse/rounded type with a "middorsal elevation" that never surpass the posterior edge of the segment and the pointed/horned type with a "middorsal process" that surpasses the posterior segment edge. It should be stressed that both types of processes can be present in the same individual but on different segments. Regarding this trait, reported very confusingly in the literature, Pycnophyes dolichurus sp. nov. shows both middorsal processes (pointed and protruding) and middorsal elevations (rounded, not protruding), whereas $P$. aulacodes sp. nov. has only middorsal elevations.

Pycnophyes dolichurus sp. nov. has middorsal elevations on segment 2 and the following five segments. On segments 8 and 9, these elevations are modified into middorsal processes. All middorsal elevations and processes are equipped with paradorsal, subcuticular, butterfly-like atria. Diagnostic characters for the species include a tergal anterior margin of the first trunk segment being strongly denticulated, a pair of paradorsal setae on segments 4,6 , and 8 , and pairs of twin paraventral setae on segments 3 to 7 . Furthermore, its lateral terminal spines are conspicuously long, more than $40 \%$ of trunk length. A feature not very common in the genus is the absence of the characteristic big adhesive tubes on the sternal plates of segment 2 in males. This last trait is only shared with three other species in the genus, namely P. ecphantor Higgins, 1983, P. egyptensis Higgins, 1966, and $P$. longicornis Higgins, 1983, but all of them have a different distribution of setae: $P$. ecphantor and $P$. egyptensis have middorsal setae and $P$. longicornis has setae present in females only, whereas $P$. dolichurus sp. nov. has no middorsal but paradorsal setae in different segments (Higgins 1966, 1983). Two additional species, P. mokievskii Adrianov, 1995, and P. spitsbergensis Adrianov 1995, have confusing descriptions, since the adhesive tubes on segment 2 are reported in the text but not illustrated in drawings (see Adrianov 1995, Figs. 7, 11, and 13).

Pycnophyes dolichurus sp. nov. is the species of the genus with the longest lateral terminal spines described so far. Other species, including $P$. longicornis, $P$. chiliensis Lang, 1953, and P. canadensis Higgins and Korczynski, 1989 also have extraordinary long lateral terminal spinesa character that enables the observer to identify these species of Pycnophyes easily. However, none of them present a TL/LTS proportion similar to $P$. dolichurus sp. nov. (Lang 1953; Higgins 1983; Higgins and Korczynski 1989). From these, the closest species in terms of lateral terminal spine length is $P$. longicornis $337.7 \%$ of TL in males). However, this species shows a transverse mark at each lateral terminal spine about three-fourths from its base. Such marks are not present in P. dolichurus sp. nov. 
The presence of paired paradorsal setae in Pycnophyes dolichurus sp. nov. is shared with $P$. parasanjuanensis Adrianov and Higgins, 1996, P. greenlandicus Higgins and Kristensen, 1988, P. faveolus (in Brown 1985, see Adrianov and Malakhov 1999) and P. kielensis Zelinka, 1928. However, $P$. dolichorus sp. nov. possesses paradorsal setae on segments 4, 6, and 8, whereas such setae are found on segment 6 only in P. parasanjuanensis and on segment 8 in P. greenlandicus (Higgins and Kristensen 1988; Adrianov and Higgins 1996). Also, P. faveolus and P. kielensis have paradorsal setae, but in these species the setae are not only restricted to segments 4, 6, and 8 . Hence, $P$. faveolus has paradorsal setae on five segments (Brown 1985), whereas such setae are present on at least eight segments in P. kielensis (not reported by Zelinka 1928), but see Neuhaus (1993) and Adrianov and Malakhov (1999).

Moreover, Pycnophyes dolichurus sp. nov. shows unique characters that are not present in any other species of the genus, such as one pair of twin setae on every sternite of segments 3-7.

Pycnophyes aulacodes sp. nov. has middorsal elevations with subcuticular butterfly-like atria on segment 1 and following segments, and on segments 4 and 6 also a pair of adjacent paradorsal setae is present. Tergal anterior margin of segment 1 is minutely denticulated, and lateroventral setae are lacking on segments 3, 5, 7, and 9 .

Pycnophyes aulacodes sp. nov. is easily recognized by the presence and appearance of muscular scars on all segments. The scars are groove-like on the tergal plates and appear crescentic on the sternal plates of segments 2-9. It should be noted that these cuticular marks show some variation among specimens, being even more conspicuous in older animals, where the cuticle becomes thicker with age. Furthermore, some species descriptions dating back to the middle of the twentieth century do not document this feature. Hence, this character should be used with caution when comparing species and specimens, and a revision and redescription of many species in the genus would be needed in order to come to sound taxonomic statements.

There are some species in which similar groove-like and crescentic muscular scars have been reported, including P. beaufortensis Higgins, 1964, P. egyptensis, P. corrugatus Higgins, 1983, P. ecphantor and P. neuhausi Martorelli and Higgins, 2004 (Higgins 1964b, 1966, 1983; Martorelli and Higgins 2004). However, P. beaufortensis, P. corrugatus and $P$. ecphantor have no middorsal elevation on segment 1. Moreover, none of these three species have paradorsal setae, although $P$. corrugatus and $P$. ecphantor show middorsal setae 2-9 and 2, 4-8, respectively. $P$. egyptensis differs from $P$. aulacodes sp. nov. by having no middorsal elevations or processes, and although middorsal setae are present (4-10, see Higgins 1966), they never possess paired paradorsal setae. Pycnophyes neuhausi has a middorsal elevation on segment 1 , but the posterior margin of this segment extends posteriorly well over the following segment. Moreover, $P$. aulacodes sp. nov. and P. neuhausi differ in their distributions of ventral setae (two pairs of setae on the sternal plates in segments 3-5 of $P$. neuhausi and only one in P. aulacodes) and in the absence of middorsal setae in $P$. neuhausi.

The presence of paradorsal setae on the segments 4 and 6 in Pycnophyes aulacodes sp. nov. is shared with P. dolichurus sp. nov., and as stated above, P. parasanjuanensis, $P$. greenlandicus, P. faveolus, and P. kielensis (Zelinka 1928; Brown 1985; Higgins and Kristensen 1988; Adrianov and Higgins 1996; Adrianov and Malakhov 1999). However, both $P$. parasanjuanensis and $P$. greenlandicus show paradorsal setae on one segment only, whereas $P$. faveolus and $P$. kielensis show paradorsal setae on more segments or the setae have a different distribution. Hence, $P$. aulacodes sp. nov. can easily be distinguished from any known species in the genus.

\section{Character evaluation}

The main source of mistakes in the determination of specimens in the genus Pycnophyes is the triangular shape of the animals in cross section, which makes it difficult to distinguish and locate some diagnostic characters using LM. Due to this, the ability to make accurate observations of the dorsal or ventral regions of the specimens depends on the specimen's orientation (dorsal or ventral up) on the glass slide. In addition, a further consequence is the difficulty to locate and discriminate laterodorsal structures because they often appear too close the lateral margins of the specimen.

These problems are best solved by the use of SEM, which allows observation from any point of view. However, SEM is restricted to provide information about cuticular surface characters, whereas LM allows observation of subcuticular structures. Hence, the optimal examination of a species is obtained when the two techniques are used in combination.

Finally, there are some characters used in identification keys that are ambiguous and lead to confusion. For example, the determination of whether a middorsal process is more or less rounded or pointed, or the exact consideration of a middorsal process that exceeds or not the segment margina feature that may vary according of the contraction or squeezing state of the specimen. Those are very subjective characters, and their accurate evaluation depends mostly on the researcher view and ability. Unfortunately, most, if not all, keys for homalorhagid kinorhynchs make frequent use of those characters and features. We hope that the description of the new species presented here and other to come in a near future will enable the preparation of completely new, unambiguous keys for homalorhagid kinorhynchs. 
Faunistic remarks

Information on kinorhynch distribution is scarce. The available data refer only to the species found in sampling localities randomly selected by several authors throughout a long timespan, whereas only few expanded areas or long coast lines have been object of systematic sampling campaigns. Hence, the distribution patterns of most kinorhynch species are not fully understood. This paper is part of a long-term study along the coasts of Spain, facing the Atlantic Ocean to the north and west and the Mediterranean to the east.

The first recordings of species of the genus Pycnophyes along the Spanish coasts were surprising. Since species of the genus not previously have been recorded from Iberian Peninsula, it was expected that the specimens collected in the sampled localities, from Galicia (NW) to the Costa Brava (NE), including Almería (SE) and the Levantine coast (E) would, at least in part, be conspecific with those that had been reported from localities close to the Iberian Peninsula. In fact, and as stated previously, 11 species of this genus have been recorded from the Atlantic Ocean and the Mediterranean Sea (Reinhard 1881; Southern 1914; Zelinka 1928; Reimer 1963; Higgins 1983; Adrianov and Malakhov 1999).

However, none of the previously recorded species were encountered among the specimens collected for the present study. This excluding distribution may be due to two reasons. First, the genus is most probably more diverse in European waters than we know currently; hence, the new species described in the present contribution will probably appear at other Atlantic and Mediterranean localities as well. Secondly, the meiofauna distribution and in particular the kinorhynch distribution is strongly patched (Gray and Rieger 1971; Mclachlan 1978; Findlay 1981; Higgins 1988). As a consequence, it is highly probable that the present sampling campaign, although more intense than other sampling around Europe, has not revealed all existing species around the Iberian Peninsula. Therefore, it should be expected that future samplings in the same or in other localities will demonstrate the presence of different species of Pycnophyes that already have been recorded elsewhere in Europe.

Pycnophyes dolichurus sp. nov. appeared only in the Ría de Ares, Galicia, NW Spain, whereas P. aulacodes sp. nov. was found on the same locality but also at the nearby Ferrol and La Coruña, as well as in the Mediterranean localities of Blanes, Garrucha and Denia, NE, SE, and E Spain. This geographical distribution suggests that $P$. dolichurus sp. nov. has a more restricted distribution, whereas $P$. aulacodes $\mathrm{sp}$. nov. probably occurs all along the Iberian coast. Nevertheless, more intense sampling campaigns should be carried out to confirm these rather different biogeographical distributions.
In addition, the two species also appear to differ in their sediment preferences. From our results, none of them appeared in shell gravel or amphioxus sand (samples not shown in Table 3), and $P$. dolichurus sp. nov. never appeared in muddy sediments. $P$. dolichurus sp. nov. is found in sandy sediments, and mostly in the fine sand. $P$. aulacodes sp. nov. prefers silty and sandy sediments, apparently with a preference for the more muddy ones.

Acknowledgments This paper received financial support from the Research Project CGL 2005-04310 (Ministerio de Ciencia y Tecnología, Government of Spain). The authors want to thank Dr. V. Urgorri, Director of La Graña Marine Station in Ferrol; Dr. S. Parra, Director of Instituto Español de Oceanografía at La Coruña, and Dr. M. Maldonado, from the Instituto de Estudios Avanzados in Blanes for their enthusiastic help during sampling campaigns. Thanks are also due to the staff of the Centro de Microscopía Luis Bru (UCM) for their excellent technical assistance with SEM. The materials, procedures and techniques used in this research comply with the current laws of Spain.

\section{References}

Adrianov AV (1995) The first description of kinorhynchs from the Spitsbergen Archipelago (Greenland Sea), with a key to the genus Pycnophyes (Homalorhagida, Kinorhyncha). Can J Zool 73:1554-1566

Adrianov AV, Higgins RP (1996) Pycnophyes parasanjuanensis, a new kinorhynch (Kinorhyncha: Homalorhagida: Pycnophyidae) from San Juan Island, Washington, USA. Proc Biol Soc Wash 109(2):236-247

Adrianov AV, Malakhov VV (1999) Cephalorhyncha of the world ocean. KMK Scientific Press Ltd, Moscow

Bãcescu M (1968) Class Kinorhyncha. Identification of the Black Sea and Azov Sea fauna. Naukova Dumka 1:237-250

Bãcescu M, Bãcescu E (1956) Kinorhinchii. Reprezentanti ai unei clase de animale, noua pentru fauna Romineasca. Comunicarile Academiei Republicii Populare Romane 6:543-549

Brown R (1985) Developmental and taxonomic studies of Sydney Harbour Kinorhyncha. Ph.D. thesis. Macquarie University, Australia, pp 193 + figures and plates

Bruce JR, Colman JS, Jones NS (1963) Marine fauna of the Isle of Man and its surrounding seas. Liverpool Marine Biology Committee LMBC Memoirs 36. 307 pp

Findlay SEG (1981) Small scale spatial distribution of meiofauna for benthos communities. Oecologia 6:176-190

Gardóñez D, Pardos F, Benito J (2008) Three new Echinoderes (Kinorhyncha, Cyclorhagida) from North Spain, with new evolutionary aspects in the genus. Zool Anz 247:95-111

Gray JS, Rieger RM (1971) A quantitative study of the meiofauna of an exposed sandy beach, at Robin Hood's Bay, Yorkshire. J Mar Biol Assoc UK 51:1-19

Higgins RP (1964a) A method for meiobenthic invertebrate collection. Am Zool 4:291

Higgins RP (1964b) Three new Kinorhynchs from the North Carolina Coast. Bull Mar Sci Gulf Caribb 14(3):479-493

Higgins RP (1966) Faunistic Studies in the Red Sea (in Winter, 1961-1962). Part II: Kinorhynchs from the Area of Al-Ghardaqa. Zoologisches Jahrbücher Systematik Oekologie Geographie der Tiere 93:118-126

Higgins RP (1983) The Atlantic barrier reef Ecosystem at Carrie Bow Cay Belize II: Kinorhyncha. Smithson Contrib Mar Sci 18:1-131 
Higgins RP (1988) Kinorhyncha. In: Higgins RP, Thiel H (eds) Introduction to the study of Meiofauna. Smithsonian Institution Press, Washington DC, pp 328-331

Higgins RP, Adrianov A (1991) Kinorhyncha from the Black Sea. I. Redescription of Kinorhynchus paraneapolitanus. Trans Am Microsc Soc 110(4):328-336

Higgins RP, Korczynski RE (1989) Two new species of Pycnophyes (Homalorhagida, Kinorhynch) from the Canadian coast of Beaufort Sea. Can J Zool 67:2056-2064

Higgins RP, Kristensen RM (1988) Kinorhynch from Disko Island, West Greeland. Smithson Contrib Zool 458:34-54

Huys R, Coomans A (1989) Echinoderes higginsi sp. n. (Kinorhyncha, Cyclorhagida) from the southern North Sea with a key to the genus Echinoderes Claparede. Zool Scr 18:211-221

Kristensen RM, Higgins RP (1991) Kinorhyncha. In: Harrison FW, Ruppert EE (eds) Microscopic anatomy of invertebrates, the Aschelminthes, vol 4. Wiley, New York, pp 377-404

Lang K (1936) Undersökningar over Öresund, XXI: Einige Kleintiere aus dem Öresund. Kungliga Fysiografiska Sällskapets Hndlingar, new series 46(10): $1-8$

Lang K (1953) Reports of the Lund University Chile Expedition 1948-49. 9. Echinoderida. Kunngl. Fysiografiska. Sällskapet I Lund Handlingar, N.F 64:1-8

Marinov T (1964) On the microzoobenthos Fauna of the Black Sea (Kinorhyncha and Halacaridae). Bull Inst Fish Cult Fish Varna KH 4:61-71

Martorelli S, Higgins RP (2004) Kinorhyncha from the stomach of the shrimp Pleoticus muelleri (Bate, 1888) from Comodoro Rivadavia, Argentina. Zool Anz 243:85-98

McIntyre AD (1962) The class Kinorhyncha (Echinoderida) in Brisish waters. J Mar Biol Assoc UK 42:503-509

McLachlan A (1978) A quantitative analysis of the meiofauna and the chemistry of the redox potential discontinuity zone in a sheltered sandy beach. Estuar Coast Mar Sci 7:275-290
Neuhaus B (1988) Ultrastructure of the Protonephridia in Pycnophyes kielensis (Kinorhyncha, Homalorhagida). Zoomorphology 108: 245-253

Neuhaus B (1993) Postembryonic development of Pycnophyes kielensis and $P$. dentatus (Kinorhyncha) from the North Sea. Microfauna Mar 8:163-193

Neuhaus B, Higgins RP (2002) Ultrastructure, biology and phylogenetic relationships of Kinorhyncha. Integr Comp Biol 42:619-632

Nyholm KG (1947) Campyloderes: an "Antarctic" genus of Echinoderida off the West coast of Sweden. Arkiv Zool 39A:1-6

Pagenstecher A (1875) Echinoderes Sieboldii. Zeitschrift für Wissenschaftliche Zoologie supplement 25(S):117-123

Pardos F, Higgins RP, Benito J (1998) Two new Echinoderes (Kinorhyncha, Cyclorhagida) from Spain including a reevaluation of kinorhynch taxonomic characters. Zool Anz 237:195-208

Reimer L (1963) Zur Verbreitung der Kinorhyncha in der Mittleren Ostsee. Zool Anz 171:440-447

Reinhard W (1881) Über Echinoderes und Desmocolex der Umgegend von Odessa. Zool Anz 4(97):558-592

Sheremetevskij AM (1974) Kinorhynchs of the Black Sea. Zool Zhurnal 53:974-987

Sørensen MV, Pardos F (2008) Kinorhynch systematics and biology an introduction to the study of kinorhynchs, inclusive identication keys to the genera. Meiofauna Mar 16:21-73

Sørensen MV, Pardos F, Herranz M, Rho HS (2010) New data on the genus Paracentrophyes (Homalorhagida, Kinorhyncha), with the description of a new species from the West Pacific. Open Zool J 3:42-59

Southern R (1914) Nemathelmia, Kinorhyncha and Chaetognatha. Part 54. In: Clare Island Survey. Proc R Ir Acad 31:1-80

Zaneveld JS (1938) Marine Gatrotricha and Kinorhyncha from Scheveningen. Zool Meddelingen. Leiden 20:247-262

Zelinka C (1928) Monographie der Echinodera. Verlag Wilhelm Engelmann, Leipzig 